\title{
SORGOdb: Superoxide Reductase Gene Ontology curated DataBase
}

\author{
Céline Lucchetti-Miganeh ${ }^{1 *}$, David Goudenège ${ }^{1}$, David Thybert ${ }^{1,2}$, Gilles Salbert $^{1}$ and Frédérique Barloy-Hubler ${ }^{1}$
}

\begin{abstract}
Background: Superoxide reductases (SOR) catalyse the reduction of superoxide anions to hydrogen peroxide and are involved in the oxidative stress defences of anaerobic and facultative anaerobic organisms. Genes encoding SOR were discovered recently and suffer from annotation problems. These genes, named sor, are short and the transfer of annotations from previously characterized neelaredoxin, desulfoferrodoxin, superoxide reductase and rubredoxin oxidase has been heterogeneous. Consequently, many sor remain anonymous or mis-annotated.

Description: SORGOdb is an exhaustive database of SOR that proposes a new classification based on domain architecture. SORGOdb supplies a simple user-friendly web-based database for retrieving and exploring relevant information about the proposed SOR families. The database can be queried using an organism name, a locus tag or phylogenetic criteria, and also offers sequence similarity searches using BlastP. Genes encoding SOR have been re-annotated in all available genome sequences (prokaryotic and eukaryotic (complete and in draft) genomes, updated in May 2010).

Conclusions: SORGOdb contains 325 non-redundant and curated SOR, from 274 organisms. It proposes a new classification of SOR into seven different classes and allows biologists to explore and analyze sor in order to establish correlations between the class of SOR and organism phenotypes. SORGOdb is freely available at http://sorgo.genouest.org/index.php.
\end{abstract}

\section{Background}

Two and a half billion years ago, the intense photosynthetic activity of cyanobacteria caused the largest environmental change in Earth's history: the oxygenation of the atmosphere and the oceans, which were hitherto largely anoxic $[1,2]$. This profound transformation of the biosphere exerted an evolutionary selection pressure on organisms and led to the development of new pathways, including the highly exergonic respiratory chain based on $\mathrm{O}_{2}$ as the terminal electron acceptor. Currently, most living organisms, except anaerobic microbes, require oxygen. $\mathrm{O}_{2}$ is used as a substrate by many enzymes involved metabolizing amines, purines and amino acids. Oxygen is a relatively inert molecule due to its spin triplet ground state. However, it can be activated by photons or by one electron oxidation or reduction processes to generate reactive oxygen species

\footnotetext{
* Correspondence: celine.lucchetti@univ-rennes1.fr

${ }^{1}$ CNRS UMR 6026, ICM, Equipe Sp@rte, Université de Rennes 1, Campus de Beaulieu, 35042 Rennes, France

Full list of author information is available at the end of the article
}

(called reactive oxygen species or ROS), particularly hydroxyl radicals $(\bullet \mathrm{OH})$, hydrogen peroxide $\left(\mathrm{H}_{2} \mathrm{O}_{2}\right)$ and superoxide anion radicals $\left(\mathrm{O}_{2}-\right)$.

The superoxide anion is generated fortuitously by flavoenzymes such as NADH dehydrogenase II, succinate dehydrogenase, fumarate reductase, and sulphite reductase $[3,4]$. The superoxide anion is one of the deleterious reactive oxygen species: it can damage DNA, proteins and lipids indirectly by releasing iron from damaged dehydratase clusters $[4,5]$. In anaerobes, most of the essential "central metabolic" redox enzymes (for example aconitase, fumarase, dihydroxyacid dehydratase, and pyruvate:ferredoxin oxidoreductase) contain iron sulphur $[\mathrm{Fe}-\mathrm{S}]$ clusters that are rapidly inactivated when exposed to oxygen [5-8].

To survive and protect themselves from the toxicity of superoxide anion, many species, and especially anaerobes, have developed defence mechanisms [5].

Superoxide dismutase (SOD) was first isolated by Mann and Keilis (1938) and its catalytic function, which consists to dismutate $\mathrm{O}_{2}$ - into molecular oxygen and
C Biomed Central

(c) 2011 Lucchetti-Miganeh et al; licensee BioMed Central Ltd. This is an Open Access article distributed under the terms of the Creative Commons Attribution License (http://creativecommons.org/licenses/by/2.0), which permits unrestricted use, distribution, and reproduction in any medium, provided the original work is properly cited. 
hydrogen peroxide, was discovered in 1969 by McCord and Fridovich [9]. Mammals have two forms of SOD isozymes: the manganese SOD (Mn-SOD), present in the mitochondria, and the copper/zinc SOD $(\mathrm{Cu} / \mathrm{Zn}-\mathrm{SO})$, present in the cytoplasm $[10,11]$. In plants, SOD have been classified into three distinct types on the basis of their metal cofactor: $\mathrm{Cu} / \mathrm{Zn}-\mathrm{SOD}$ (in the cytosol and chloroplasts), Mn-SOD (in mitochondria), and Fe-SOD (often in chloroplasts) [12-14]. There are three known SOD in E. coli: MnSOD, FeSOD and CuZnSOD. The two first are located in the cytoplasm and the last in the periplasmic space [15]. A distinct additional fourth class of SOD containing nickel (NiSOD) was recently discovered in Streptomyces [16,17] and cyanobacteria [18]. SODdriven dismutation was the only biological mechanism identified for scavenging superoxide anion radicals until the early 1990's. McCord et al. [19] established a correlation between oxygen tolerance and SOD production and suggested that SOD was the single most important enzyme for enabling organisms to survive in the presence of molecular oxygen. They proposed that the hypersensitivity of obligate anaerobes to oxygen was a consequence of SOD deficiency. However, most anaerobic organisms, which indeed lack SOD, show various degrees of tolerance to oxygen when they are occasionally exposed to this molecule in their environments.

Two novel iron-sulphur-containing proteins that detoxify superoxide molecules were then discovered in sulphate-reducing and hyperthermophilic anaerobes: desulfoferrodoxin (Dfx) in Desulfovibrio desulfuricans, Desulfovibrio vulgaris Hildenbourgh [20] and Desulfoarculus baarsii [21], neelaredoxin (Nlr) in Desulfovibrio gigas [22] and superoxide reductase (SOR) in Pyrococcus furiosus [23]. This revealed the existence of alternative mechanisms for ROS detoxification in anaerobes. The function of these proteins was first studied in 1996 by Dfx complementation of superoxide detoxication activity in E. coli SOD mutants [24]. Later, Nlr from Treponema pallidum [25] and D. gigas [26] were also shown to complement such SOD mutants. Liochev and Fridovich [27] suggested that Dfx catalyzes the reduction of superoxide rather than its dismutation, and that it uses cellular reductants such as NAD $(\mathrm{P}) \mathrm{H}$. Subsequently, the Dfx enzyme was confirmed as an oxidoreductase [23-25,27]. Finally, the superoxide reductase activity of those proteins were established by two groups $[21,23]$.

Dfx and Nlr proteins have different numbers of iron sites: both contain a similar C-terminal single ironcontaining site (centre II) but also has Dfx a second $\mathrm{N}$ terminal site (centre I) $[22,28]$. Centre II is the active site of SOR and consists of a pentacoordinated $\mathrm{Fe}^{2+}$ centre with four equatorial histidines and one axial cysteine in a square pyramidal geometry $\left(\mathrm{Fe}(\mathrm{His})_{4}(\mathrm{Cys})\right.$ [29-31]). The binding site for the substrate $\mathrm{O}_{2}$ - is the free sixth axial site of the reduced enzyme centre [30]. The additional $\mathrm{N}$-terminal domain of the $2 \mathrm{Fe}-\mathrm{SOR}$ contains a rubredoxin-like centre, with $\mathrm{Fe}^{3+}$ ligated by four cysteines in a distorted tetrahedral geometry (centre I, $\mathrm{Fe}(\mathrm{Cys})_{4}$, [32]). A first classification of these enzymes was proposed according to the number of metal centres: neelaredoxin or $1 \mathrm{Fe}-\mathrm{SOR}$ and desulfoferrodoxin or $2 \mathrm{Fe}-$ SOR $[33,34]$. An additional class was proposed after the isolation of a Treponema pallidum SOR that contains an extended non-iron $\mathrm{N}$-terminal domain of unknown function $[25,35]$. In all these three classes, only the reduced form of the iron-containing active centre II is able to react with the superoxide anion $\mathrm{O}_{2} \bullet^{-}$.

SOD are found in nearly every living organism except in some strictly anaerobic species [36,37]. Tally et al suggested that the diversity in the oxygen tolerance of anaerobes is generally related to their level of SOD [38]. SOR were first thought to be restricted to anaerobic prokaryotes but were subsequently discovered in some micro-aerophilic and micro-aerotolerant Bacteria and Archaea [39,40]. More recently, a SOR encoding gene was also discovered in an eukaryote, Giardia intestinalis, a microaerophilic protozoan (cited by [41]). Although SOD and SOR both detoxify superoxide, there is a fundamental difference in their properties: SOD generate one-half mole of oxygen and one-half mole of hydrogen peroxide per superoxide molecule whereas SOR produce only one mole of hydrogen peroxide. The physiological conditions, that determine SOR or SOD preference in organisms, have not be completely determined, although the presence of SOR rather than SOD may be associated with the amount of redox proteins produced by organisms [25].

Most genomes, even those of anaerobic species, contain both SOD and SOR although some species have only one of the two enzymes. The increasing number of sequenced genomes makes allows comparative genomic analyses, to elucidate the evolutionary or functional processes of SOR. Unfortunately, there are several problems with the annotation of superoxide reductase genes, partly a consequence of heterogeneous transfer of annotations from previously characterized neelaredoxin, desulfoferrodoxin, superoxide reductase or rubredoxin oxidase. Moreover, due to the absence of updating or correction of databases, many sor genes remained anonymous because of the transfer of annotations from SOR genes initially annotated as "hypothetical", "function unknown" or "putative activity". Also, SOR are small proteins, ca. 200 amino acids on average, and mis-annotations are frequent for proteins of this length [42].

For all these reasons, we developed SORGOdb, the first resource specifically dedicated to superoxide reductase genes in entirely sequenced and in-draft genomes. SOR sequences were curated manually, analysed and 
stored using a new ontology in a publically available resource (http://sorgo.genouest.org/). SOR genes were detected in the three kingdoms of life, and only on chromosomal replicons. Although no N-terminal signal sequences were previously described for bacteria SOR [43], we predicted seven SOR to be potentially TATsecreted (Twin-arginine translocation) in some bacteria, including for example in Desulfovibrio salexigens DSM 2638, Desulfuromonas acetoxidans DSM 684 and Geobacter uraniireducens Rf4. Our analysis confirms the observations by Pinto et al in 2010 that (1) the repartition of SOR classes does not correlate with organism phylogeny and that (2) sor genes occur in very diverse genetic environments. Indeed, although some sor are clustered with genes encoding electron donors (such as rubredoxin in D. vulgaris) or inter-related oxidative responsive genes, most are close to functionally unrelated genes. This is consistent with sor genes being acquired, or lost, through lateral gene transfer [41].

\section{Construction and content}

\section{Collection of SOR}

For collection of SOR, we have extensively searched the Pubmed database and identified all relevant literature concerning any protein with "superoxide reductase" activity; this search resulted in a small dataset (13 SOR published in 12 organisms, see Table 1). We therefore enriched the database using manually curated sequences described as desulfoferrodoxin (160 proteins), superoxide reductase (50 proteins) or neelaredoxin (9 proteins) in EntrezGene and/or GenBank entries. As the "centre II" is the active site for the SOR activity, we also included all proteins with a domain of this type as described in InterPro (IPR002742, IPR004793, IPR004462, IPR012002), Pfam (PF01880, PF06397),
Supfam (SSF49367), TIGRfam (TIGR00332, TIGR00320, TIGR00319), NCBI conserved domains (cd03172, cd03171, cd00524, cl00018, cl00014, cd00974) and PRODOM (PD006618, PD330262, PDA2O7Z7, PDA36750, PD985590, PDA36751, PDA63215, PDA7Y161, PDA7Y162, PD511041, PD171746, PD985589, PDA7Y163). All sequences collected were cleaned up to remove redundancy and unrelated proteins. This non-redundant and curated dataset was used to investigate the 1237 complete and 1345 in-draft genomes available in the NCBI database (May, 2010) through a series of successive BlastP [44] and tBlanstN [45] searches. Orthology (KO K05919 and COG2033) and synteny (IMG neighbourhood interface) were also exploited. To be as comprehensive as possible in the data collection, we performed multiple alignments using both ClustalW $[46,47]$ and Muscle [48] algorithms. These alignments showed highly conserved residues in the sequences of active centre I $\left(\mathrm{CX}_{2} \mathrm{CX}_{15} \mathrm{CC}\right)$ and centre II $\left(\mathrm{HX}_{5} \mathrm{H}-\mathrm{CX}_{2} \mathrm{H}\right)$. These conversations were translated into "regular expressions" that were used to perform for final screening of databases. All these search processes allowed us to retrieve 106 supplementary proteins including 82 proteins described as "hypothetical protein".

At the end of this integrative research, we had a collection of 325 non-redundant and curated predicted SOR in 274 organisms, covering all the three kingdoms: Bacteria (270 genes), Archaea (52 genes) and Eukaryota (3 genes).

\section{New Classification and ontology}

Consistent with the collecting procedure, all the 325 proteins present in SORGOdb contain at least the SOR active centre II domain. However, we found that this SOR module is, in some cases, associated with other domains, in a modular way. The discovery of new

Table 1 SOR proteins with entrie(s) in Pubmed and/or PDB structure

\begin{tabular}{|c|c|c|c|}
\hline Organism & Locus Tag & PDB & PMID \\
\hline Desulfovibrio desulfuricans ssp. desulfuricans. ATCC 27774 & Ddes_2010 & 1DFX & {$[20,56,76-78]$} \\
\hline Desulfovibrio Desulfuricans ssp. desulfuricans G20 & Dde_3193 & $2 J 3,2 J \mid 2$ & [79] \\
\hline Desulfoarculus baarsii & rbo & $2 J 11,1 \mathrm{VZI}, 1 \mathrm{VZG}, 1 \mathrm{VZH}$ & {$[25,52,79-87]$} \\
\hline Pyrococcus horikoshii Ot3 & PH1083 & $2 \mathrm{HVB}$ & [30] \\
\hline Pyrococcus furiosus DSM 3638 & PF1281 & 1DQI, 1DO6, 1DQK & {$[29,30,88-91]$} \\
\hline Treponema pallidum ssp. pallidum str. Nichols & TP0823 & $1 Y 07$ & {$[21,35,52,82,86,92-99]$} \\
\hline Treponema maritima & & $2 \mathrm{AMU}$ & \\
\hline Archaeoglobus fulgidus DSM 4304 & AF0833, AF0344 & & {$[51,55,100-103]$} \\
\hline Desulfovibrio vulgaris 'Miyazaki F & DVMF_2481 & & [104] \\
\hline Desulfovibrio vulgaris sp. vulgaris str. Hildenborough & DVU3183 & & {$[20,54,97,105-108]$} \\
\hline Desulfovibrio gigas & nlr & & {$[22,26,109]$} \\
\hline Clostridium acetobutylicum ATCC 824 & CAC2450 & & {$[110,111]$} \\
\hline Nanoarchaeum equitans Kin4-M & NEQ011 & & [112] \\
\hline
\end{tabular}

PDB: Protein Data Bank (http://www.pdb.org/pdb/home/home.do).

PMID: PubMed unique identifier (http://www.ncbi.nlm.nih.gov/pubmed). 
combinations of domains makes the previous classification into three classes inappropriate. Indeed, we suggest that the existence of multi-domain SOR indicates new function due to cooperation between domains. As previously proposed, the concept of orthology is more relevant at the level of domains than at the level of whole proteins except for proteins with identical domain architectures $[49,50]$. We therefore propose a new unambiguous SOR classification based on their domain architectures (sequential order of domains from the $\mathrm{N}$ - to the C-terminus [49]). Considering both domain compositions and arrangements, this classification contains seven functionally relevant classes which were precisely described on the website (http://sorgo.genouest. org/classif.php, additional file 1 and Table 2). Briefly, the 144 proteins that contain only the active site II (SOR) without other additional domains or cofactors have been classified as Class II-related SOR and correspond to the previous SOR class II $[20,22,23,51]$. Class III-related SOR correspond to the previous SOR class III proteins which have the active site II and enclose an additional $\mathrm{N}$-terminal region of unknown function $[25,35,52]$. Class-IV related SOR correspond to very recently new class of methanoferrodoxin [53] which have the active site II and an additional iron sulfur domain. The TATSOR have the active site II and include an extra twinarginine $\mathrm{N}$-terminal signal peptide. The 152 proteins composed of a desulforedoxin (Dx) domain preceding the SOR unit (formerly Class I [20,21,54-56]) were clustered in a class named Dx-SOR. The 19 proteins that combined a N-terminal helix-turn-helix domain ( $\mathrm{HTH})$ before the Dx-SOR module were gathered in a separate class called HTH-Dx-SOR. Finally, 10 SOR proteins that correspond to exceptional domains fusion or that encompass a mutated ncDx domain (frameshift or mutation in the conserved CXXCX15CC metal binding residues) were classified in a disparate class labelled "Atypical-SOR". This class is quite heterogeneous but includes all proteins whose composite or mutated structure might suggest a function different of the three previous classes or, in the case of mutants, a nonfunctionality due to the loss of key binding sites.

\section{SORGOdb website construction}

SORGOdb is a relational database built on MySQL and accessed from a PHP web-based interface (phpMyAdmin, Ratschiller, 2000) with additional JavaScript and JQuery functionalities (Jquery JavaScript library released

Table 2 Classes of SOR in SORGOdb (Number of proteins per classes)

\begin{tabular}{ccccc}
\hline SOR in SORGOdb & Dx-SOR & SOR & HTH-SOR & Atypical SOR \\
325 & 152 & 144 & 19 & 10 \\
\hline
\end{tabular}

in 2006 by John Resig). The database runs with the Apache web server version 2.2.3, hosted at the BioGenouest bioinformatics platform (http://www.genouest.org/). The sequences, features and annotations were introduced into the database using Python-based scripts.

\section{SORGOdb Web interface}

SORGOdb includes both documentation and search options. The web interface is composed of two panels (Figure 1).

The navigation menu (on the left) provides access to SORGOdb functions through three modules. (i) Browse: browse SOR proteins according to phylogeny criteria (kingdom, phylum, class and order) or locus tag name. (ii) Search: by organism name query and by sequence similarity through a BlastP form that allows users to enter primary sequences to find similar entries into the SORGOdb database and (iii) Pre-computed Results that include data statistics (organized in three tabs), classes (details about SORGOdb classes and ontology) and useful links (reference, tools and websites). Statistical results about SORGOdb classification were presented in the Classification tab (http://sorgo.genouest.org/classif-Stat.php).

The results panel (on the right) provides intermediary selection options and displays SOR record information in a tabular way including organism name, locus tag name, SORGOdb classification and domains architecture. When available, SORGOdb includes a CGView [57] representation of the distribution of SOR and all SOD genes (MnSOD, FeSOD CuZnSOD and NiSOD) [36] in the replicons and a gView [58] map to illustrate the genetic organisation and encoded functions surrounding each SOR (window of 11 genes max.).

\section{SORGOdb synopsis and download}

Using checkboxes, amino acid sequences and bibliography links can be obtained and synopsis cart can be downloading in .pdf format (Figure 2). Synopsis were created and pre-computed for each SOR (using Python scripts and PHP library FPDF v1.6, http://www.fpdf. org/) in order to highlight key findings in an unified manner with all protein information (locus tag, ID, organism name, replicon and genome status), previous (PRODOM, PFAM and CDD) and new (SORGOdb) classification, position in the SORGOdb distance tree, SOR cellular localization prediction using CoBaltDB [59], genomic organisation for SOR and SOD loci, synteny viewer, PMID and PDB references. Images were generated using Python scripts from CGview (genomic map), MyDomains (SORGOdb domains representation), CDD, PFAM and PRODOM (database domains illustration), gView (synteny organisation) and from FigTree (for distance tree; http://tree.bio.ed.ac.uk/software/figtree). 


\section{A}
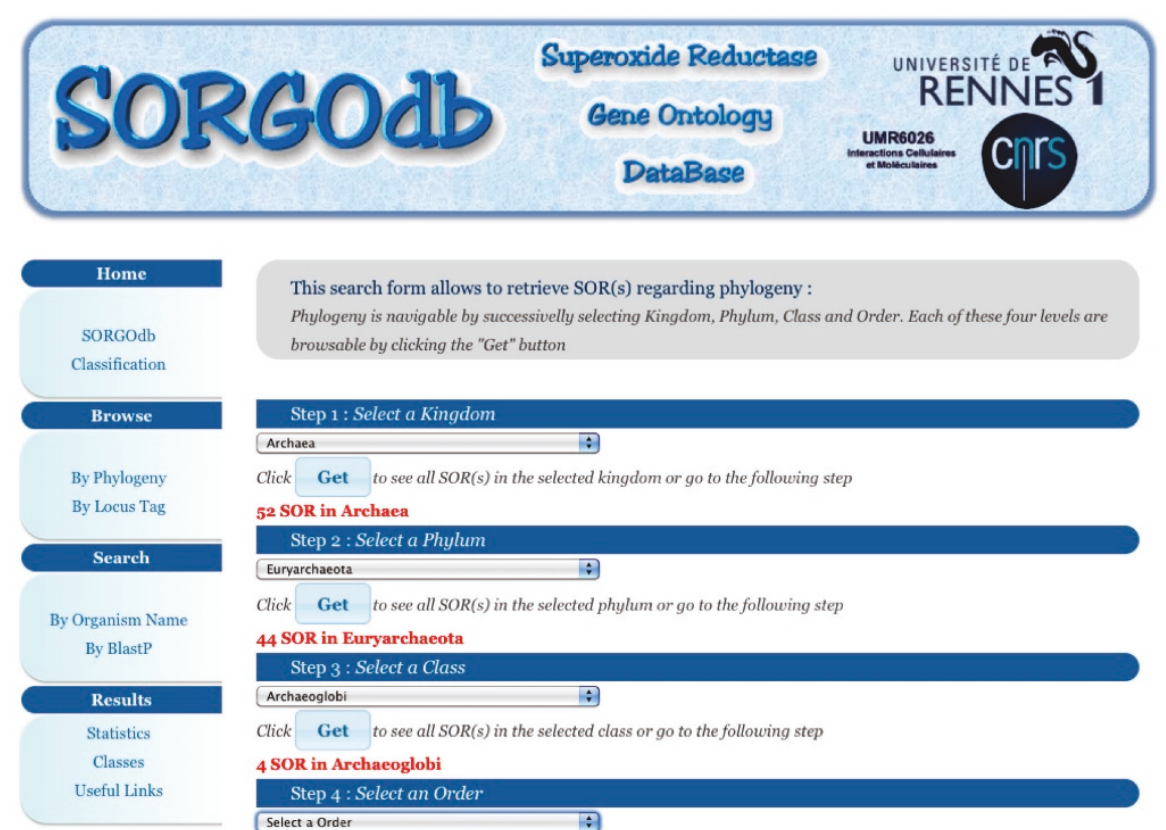

This search form allows to retrieve SOR(s) regarding phylogeny :

Phylogeny is navigable by successivelly selecting Kingdom, Phylum, Class and Order. Each of these four levels are

browsable by clicking the "Get" button

\section{Step 1: Select a Kingdom}

Click Get to see all SOR(s) in the selected kingdom or go to the following step

52 SOR in Archaea

\section{Step 2 : Select a Phylum}

Euryarchaeota

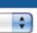

Click Get to see all SOR(s) in the selected phylum or go to the following step

44 SOR in Euryarchaeota

Step 3 : Select a Class

Archaeoglobi is

Click Get to see all SOR(s) in the selected class or go to the following step

4 SOR in Archaeoglobi

Step 4 : Select an Order

Select a Order

\section{Please cite the following reference for this database: C. Lucchetti-Miganeh, D. Goudenège, D. Thybert, G. Salbert and F. Barloy-Hubler. $\quad$ CONTACT US \\ SORGOdb: Superoxide Reductase Gene Ontology DataBase.

B

\section{SORGO results for Archaeoglobi}

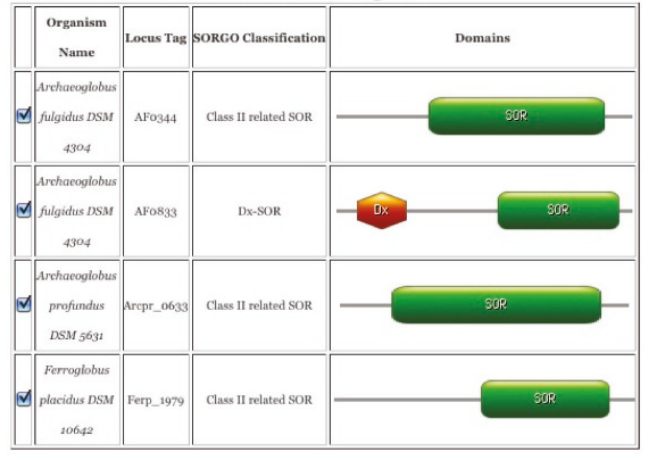

Check All Uncheck All

INCLUDE FOR EACH CHECKED LOCUS TAG :

$₫$ Amino Acid sequence

Synopsis

『 Bibliography

Get
C Amino Acid Sequence in FASTA format MAP0344 AOKKEKHVPVIEVLRAEGGVVEVKVSVGKEIPHPNTTEHHIANIRLVEOPEGSKFPYVUGRAEFAABGA

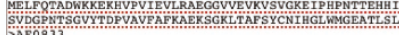

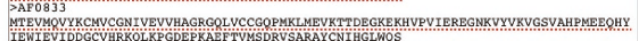

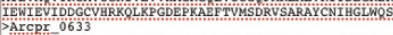

ATCP 033
MLTKR YSKERAEEIISKVETHTPEIECPDVVRAGEPFEVRISVTKHPNKLEHSIRYVDVFFIEEGRAFNPVKVA

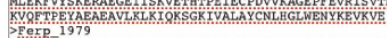

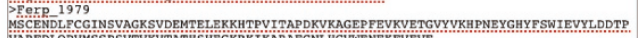

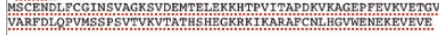

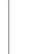

Bibliography Links

\begin{tabular}{|c|c|c|}
\hline LocusTag & PDB link(s) & PMID link(s) \\
\hline AF0 344 & No PDB & No PMID \\
\hline \hline AFo833 & No PDB & No PMID \\
\hline Arcpr_0633 & No PDB & No PMID \\
\hline Ferp_1979 & No PDB & No PMID \\
\hline
\end{tabular}

Download Synopsis

AF0344.pdf (Archaeoglobus fulgidus DSM 4304)

AFo833.pdf (Archaeoglobus fulgidus DSM 4304)

Arcpr 0633.pdf (Archaeoglobus profundus DSM 5631)

Ferp_1979.pdf (Ferroglobus placidus DSM 10642)

Download all Archaeoglobi Synopsis

Figure 1 A snapshot of the SORGOdb input interface. (A) The "Browse By Phylogeny" module allows the selection of organisms with an SOR, using complete phylogeny criteria (kingdom, phylum, class and order). (B) The results panel provides intermediary selection options and displays SOR record information in a tabular way including organism name, locus tag name, SORGOdb classification and domain architecture. (C) Using checkboxes, amino acid sequences and bibliography links can be obtained and the synopsis can be downloading in .pdf format. 


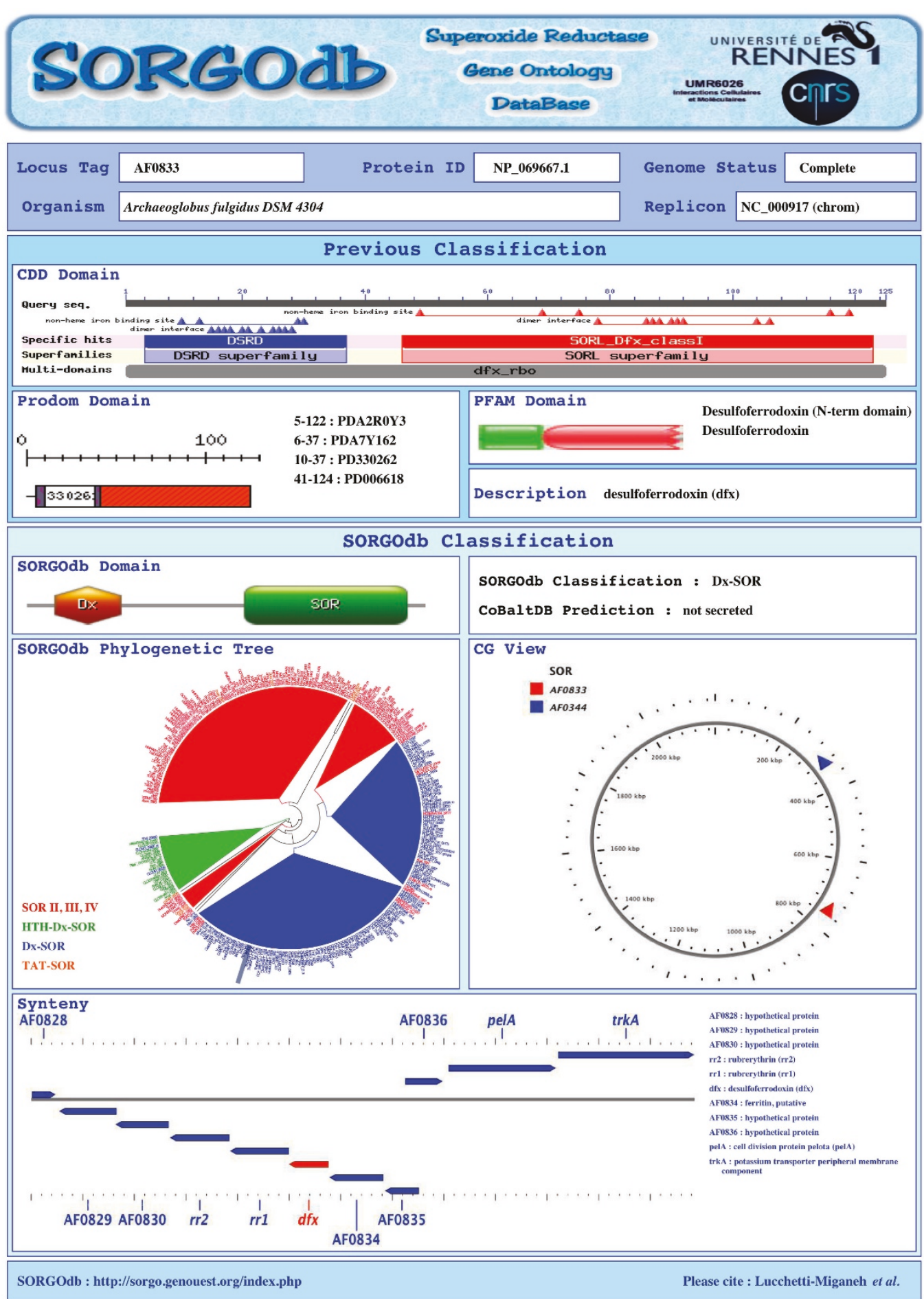

Figure 2 SORGOdb Synopsis. For any given protein, all results are summarized in a synopsis which presents results from disparate resources in an unified manner, and includes (i) the previous classification with the SOR description, the domain predictions (ii) the SORGOdb classification with domain representations, the SOR cellular localization prediction, the phylogenetic tree, the position of the sor gene and in some cases the sod gene on the replicon and the local synteny (iii) and bibliography and PDB links when available. This synopsis can be stored as a .pdf file. 


\section{Utility and Dicussion}

As an example, SORGOdb allows the study of the distribution of genes encoding superoxide reductase across a whole phylum. As a case study, we decided to consider the Archaea as these organisms are considered to be originate from a hyperthermophilic anaerobic common ancestor and were probably already prevalent when the Earth had its primative anoxic $\mathrm{H}_{2}$ and $\mathrm{CO}_{2}$ atmosphere.

Using the "Browse by phylogeny" option of SORGOdb, we collected the names of all Archaea that possess at least one SOR gene in their complete or partial genomes. Then, we generated a $16 \mathrm{~S}$-based phylogenetic tree for these organisms, using ClustalW [46] and sequences recovered from the SILVA comprehensible ribosomal RNA databases [60] (http://www.arb-silva.de/), clustered by Maximum Likelihood and Neighborhood joining algorithms (Neighborhood joining tree is not shown). This tree was annotated with the class of SOR and the presence of SOD on the genome (Maximum Likelihood Tree; Figure 3).

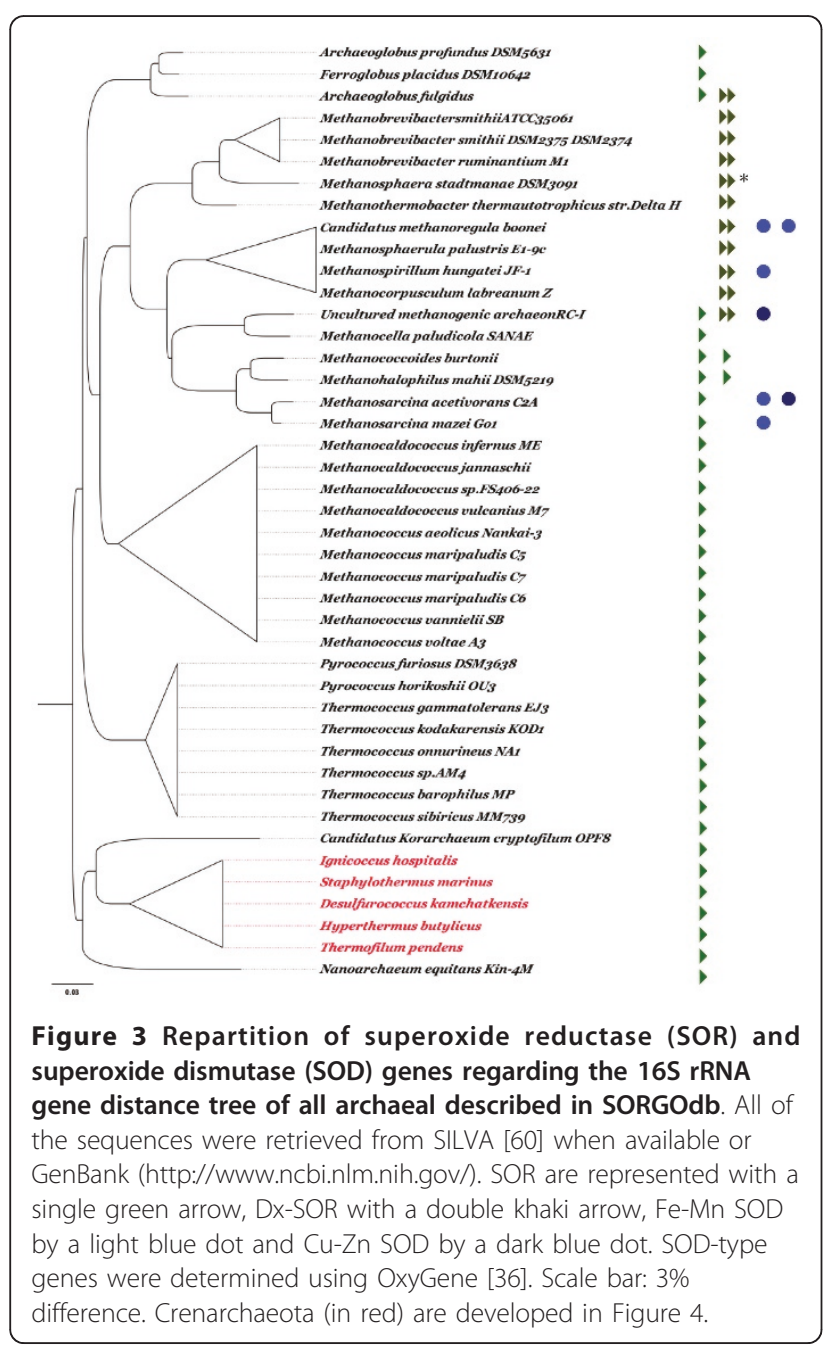

Nanoarchaeota [61] and Korarchaeota [62] are obligately anaerobic sulphur-dependent organisms placed close to the root of the archaeal SSU rRNA tree. Nanoarchaeota is currently known from a single organism Candidatus Nanoarchaeum equitans, a hyperthermophilic symbiont that grows on the surface of Ignicoccus hospitalis $[62,63]$. There are currently no representatives of Korarchaeota in pure culture but the genome of $K$. cryptophilum, a very thin filamentous thermophilic heterotroph, has been determined from a sample of Yellowstone National Park Obsidian Pool. Both C. N. equitans and K. cryptophilum are found together in the 16S tree, in the vicinity of the Crenarchaeota group, and contain genes encoding superoxide reductase with a SOR (centre II) functional domain and do not encode superoxide dismutase genes.

According to $16 \mathrm{~S}$ rRNA gene sequences, the Crenarchaeota group can be subdivided into three orders, the Thermoproteales, the Sulfolobales and the Desulfurococcales [64]. All Sulfolobales and Thermoproteoles genomes studied encode a single SOD, with the single exception of the unique member of the Thermofilaceae familly, Thermofilum pendens, an anaerobic commensal that encodes a SOR. By contrast, all Desulfurococcales genomes available encode a SOR but not a SOD, except Aeropyrum pernix that has the particularity to be strictly aerobic [65] and that encodes an extremely thermostable $\mathrm{Mn} / \mathrm{Fe}$ superoxide dismutase [66] and Ignisphaera aggregans, a novel deepbranching member of the Desulfurococcaceae lineage of strict anaerobes (as even trace quantities of oxygen inhibited its growth, [67] ) the genome of which carries neither SOR or SOD genes. Other Desulfurococcales studied (Figure 4) have all a gene encoding a centre II monodomain SOR-type enzyme. Interestingly, two recent genomes have been made available since the last update of SORGOdb (May 2010) and both contain annotation for SOR-like genes: Tagg_0590, described as a Desulfoferrodoxin ferrous iron-binding protein of Thermosphaera aggregans DSM 11486 and Shell_0770 for Staphylothermus hellenicus DSM 12710, annotated as a twin-arginine secreted superoxide reductase, by homology with Geobacter metallireducens GS-15 Gmet_2613 SOR. Using the SORGOdb "search by BlastP", we could confirm that both ORFs are true SOR (ten best e-value from e-59 to e-34) and belong to the SOR-type class. This analysis contradicts the annotation of Shell_0770 in NCBI as TAT-SOR; the absence of a significant TAT targeting signal in Shell_0770 was tested and confirmed by TatFind [68] and TatP [69] predictions. The SORGOdb "search by BlastP" tool therefore allows the accuracy of public SOR annotations to be checked and allows suggestions of their possible SORGOdb classification.

Thermococcus and Pyrococcus are obligate anaerobes that live in environments where there is no oxygen and 


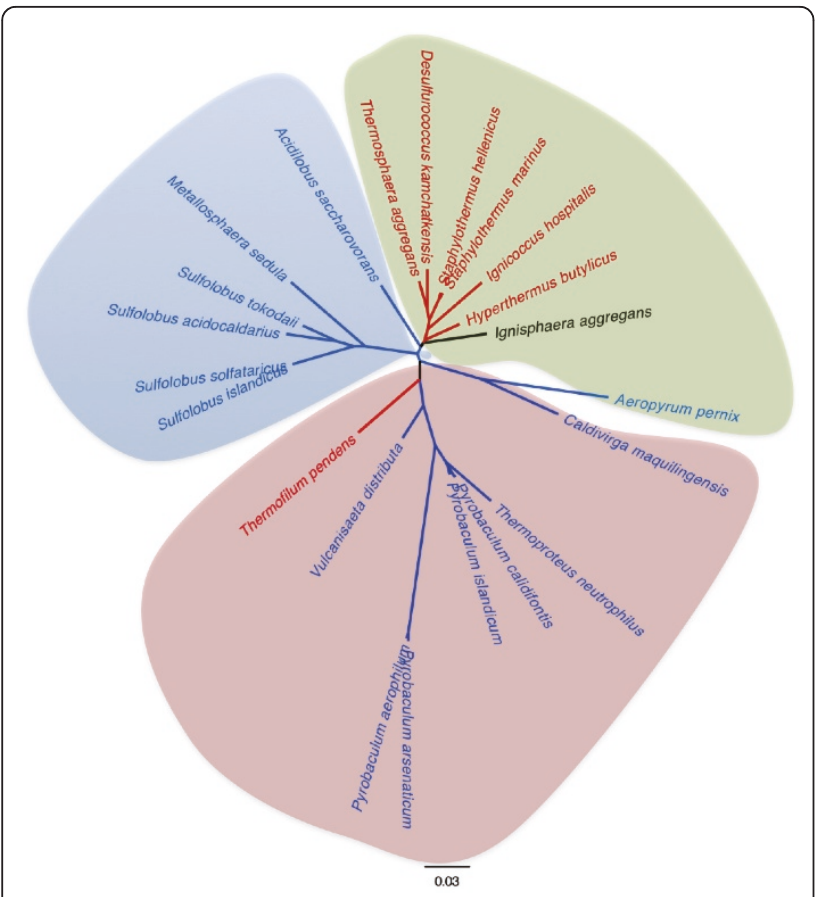

Figure 4 Repartition of superoxide reductase (SOR) and superoxide dismutase (SOD) genes regarding the 16S rRNA gene distance tree of all Crenarchaeota described in SORGOdb. All of the sequences were retrieved from SILVA [60] when available or GenBank (http://www.ncbi.nlm.nih.gov/). The Thermoproteales are highlighted in red, the Sulfolobales in blue and the

Desulfurococcales in green. Organisms having at least one SOR, or one SOD or none of both (any SOD and any SOR) are respectively represented in red, blue and dark. encode related functions, the genetic organization and order, are not conserved. Again using the "Browse by phylogeny" option of SORGOdb, we get quickly all archaeal SOR amino acid sequences (using check all then get all amino acid sequence) can be selected and used to cluster by Maximum Likelihood using ClustalW to produce a protein distance-tree (Figure 3). This tree shows the position of each four proteins considered (AF0833, AF0344, Arcpr_0633 and Ferp_1979) and indicate that the two A. fulgidus SOR (Figure 5, point 3 and 5 ) are very distant from those of $A$. profundum and $F$. placibus, which by contrast are closely related (Figure 5, point 4 ). This proximity cannot be linked to the origin of the organisms as A. fulgidus and F. placibus originate from a shallow marine hydrothermal system at Volcano, Italy $[70,71]$ whereas $A$. profundus was isolated from a deep sea hot vent area (depth: $2000 \mathrm{~m}$ ) at Guaymas, Mexico [72]. However, based on 16S rRNA gene sequences, indicate that $A$. profundus and $F$. placidus are the most closely related with $96.5 \%$ sequence identity.

The protein tree also revealed two interesting phenomena: Msp_0788 that is a non-canonical Dx-SOR (as the Dx active site is incomplete) that is branched as an out-group close to the entire archaeal Dx-SOR group (Figure 5, point 1). This is consistent with the presumed loss-of-function of Dx of Msp_0788 being relatively recent. Also, the Kcr_1172 locus forms a major divergent branch (Figure 5, point 2).). Using the "Browse by locus tag" option, Kcr_1172 is revealed to be a fusion protein with an additional $\mathrm{C}$-terminal module sharing significantly similarities with archaeal proteins annotated

both produce a SOR-type superoxide reductase that is catalytically active at temperatures below the optimum growth temperature but representing conditions likely corresponding to zones of oxygen exposure [23].

Archaeoglobus is a true archaeal sulphate reducer, reducing $\mathrm{SO}_{4}{ }^{2-}$ to $\mathrm{H}_{2} \mathrm{~S}$ in hot marine sediments. Two complete Archaeoglobus genomes are available, A. fulgidus and A.profundus, The A. fulgidus genome contains one SOR and one Dx-SOR, and the two enzymes have similar kinetics of the superoxide reduction. This raises the question of functional redundancy as Dx-SOR is absent from A. profundus and from the related Ferroglobus placidus, an iron-oxidising nitrate-reducing species that lives in anoxic (oxygen free) and hot $\left(85^{\circ} \mathrm{C}\right)$ environments [70]. The A. profundus genome $(1.6 \mathrm{Mb})$ is significantly smaller than those of A. fulgidus $(2.2 \mathrm{Mb})$ and F. placidus $(2.2 \mathrm{Mb})$. Using the SORGOdb "by organism name search" option, it is easy to compare the genomic locations (GC view map) and the genes contexts (gview synteny map) of the SOR of these three species. This visualization reveals that these genes have different genetic locations and, although the neighbouring genes

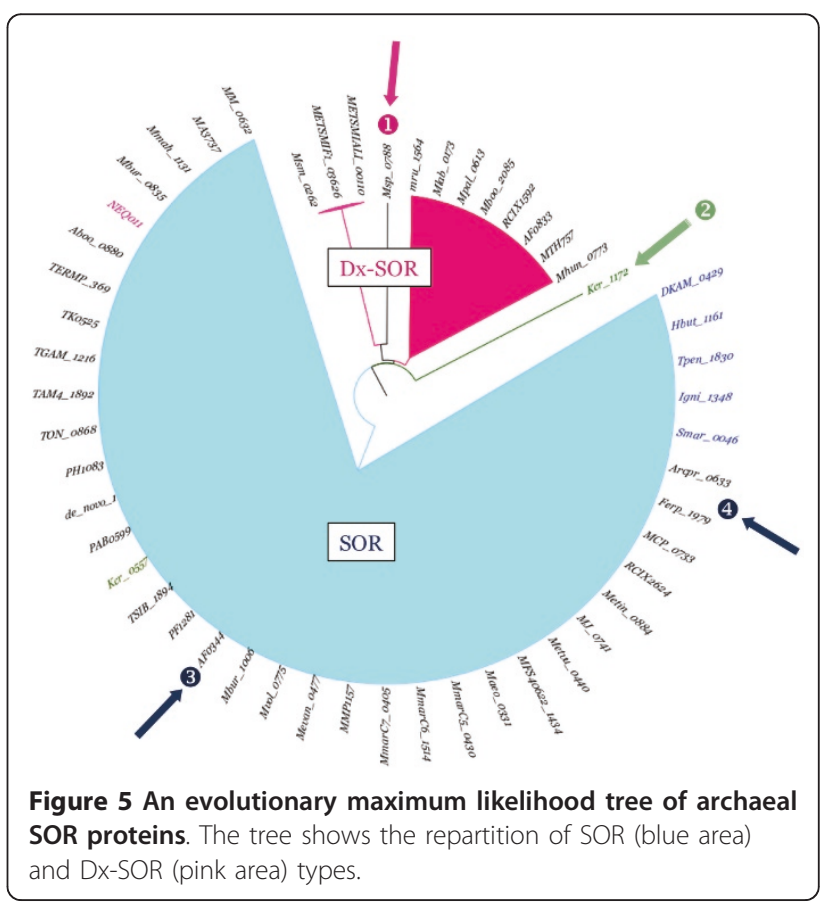


(sequence, reference, ontology...) and illustrated the relational database. DT and DG performed scripts for automated data retrieval. CLM developed the original web pages and FBH proposed design improvements. DG and CLM worked together on the PHP code. DG conceived the synopsis computation and performed all debugging activities. CLM and FBH wrote the manuscript. FBH managed the project. GS is the Sp@rte team leader and provides CLM financial support. All authors read and approved the final manuscript.

Received: 15 December 2010 Accepted: 16 May 2011

Published: 16 May 2011

\section{References}

1. Holland HD: The oxygenation of the atmosphere and oceans. Philos Trans R Soc Lond B Biol Sci 2006, 361(1470):903-915.

2. Kasting JF: Earth's early atmosphere. Science 1993, 259(5097):920-926.

3. Massey V, Strickland S, Mayhew SG, Howell LG, Engel PC, Matthews RG, Schuman M, Sullivan PA: The production of superoxide anion radicals in the reaction of reduced flavins and flavoproteins with molecular oxygen. Biochem Biophys Res Commun 1969, 36(6):891-897.

4. Imlay JA: Cellular defenses against superoxide and hydrogen peroxide. Annu Rev Biochem 2008, 77:755-776.

5. Imlay JA: Pathways of oxidative damage. Annu Rev Microbiol 2003, 57:395-418.

6. Kuo CF, Mashino T, Fridovich I: alpha, beta-Dihydroxyisovalerate dehydratase. A superoxide-sensitive enzyme. J Biol Chem 1987, 262(10):4724-4727.

7. Flint DH, Tuminello JF, Emptage MH: The inactivation of Fe-S cluster containing hydro-lyases by superoxide. J Biol Chem 1993, 268(30):22369-22376

8. Adams MW, Holden JF, Menon AL, Schut GJ, Grunden AM, Hou C, Hutchins AM, Jenney FE Jr, Kim C, Ma K, et al: Key role for sulfur in peptide metabolism and in regulation of three hydrogenases in the hyperthermophilic archaeon Pyrococcus furiosus. J Bacteriol 2001, 183(2):716-724.

9. McCord JM, Fridovich I: Superoxide dismutase. An enzymic function for erythrocuprein (hemocuprein). J Biol Chem 1969, 244(22):6049-6055.

10. Sturtz LA, Diekert K, Jensen LT, Lill R, Culotta VC: A fraction of yeast Cu,Znsuperoxide dismutase and its metallochaperone, CCS, localize to the intermembrane space of mitochondria. A physiological role for SOD1 in guarding against mitochondrial oxidative damage. J Biol Chem 2001, 276(41):38084-38089.

11. Landis GN, Tower J: Superoxide dismutase evolution and life span regulation. Mech Ageing Dev 2005, 126(3):365-379.

12. Abreu IA, Cabelli DE: Superoxide dismutases-a review of the metalassociated mechanistic variations. Biochim Biophys Acta 2010, 1804(2):263-274

13. Pilon $M$, Ravet $K$, Tapken $W$ : The biogenesis and physiological function of chloroplast superoxide dismutases. Biochim Biophys Acta 2010.

14. Myouga F, Hosoda C, Umezawa T, lizumi H, Kuromori T, Motohashi R, Shono $Y$, Nagata N, Ikeuchi M, Shinozaki K: A heterocomplex of iron superoxide dismutases defends chloroplast nucleoids against oxidative stress and is essential for chloroplast development in Arabidopsis. Plant Cell 2008, 20(11):3148-3162.

15. Hassan HM: Microbial superoxide dismutases. Adv Genet 1989, 26:65-97.

16. Youn HD, Kim EJ, Roe JH, Hah YC, Kang SO: A novel nickel-containing superoxide dismutase from Streptomyces spp. Biochem J 1996, 318(P 3):889-896.

17. Youn HD, Youn H, Lee JW, Yim Yl, Lee JK, Hah YC, Kang SO: Unique isozymes of superoxide dismutase in Streptomyces griseus. Arch Biochem Biophys 1996, 334(2):341-348.

18. Palenik B, Brahamsha B, Larimer FW, Land M, Hauser L, Chain P, Lamerdin J, Regala W, Allen EE, McCarren J, et al: The genome of a motile marine Synechococcus. Nature 2003, 424(6952):1037-1042

19. McCord JM, Keele BB Jr, Fridovich I: An enzyme-based theory of obligate anaerobiosis: the physiological function of superoxide dismutase. Proc Natl Acad Sci USA 1971, 68(5):1024-1027.

20. Moura I, Tavares P, Moura JJ, Ravi N, Huynh BH, Liu MY, LeGall J: Purification and characterization of desulfoferrodoxin. A novel protein from Desulfovibrio desulfuricans (ATCC 27774) and from Desulfovibrio vulgaris (strain Hildenborough) that contains a distorted rubredoxin center and a mononuclear ferrous center. J Biol Chem 1990, 265(35):21596-21602

21. Lombard M, Fontecave M, Touati D, Niviere V: Reaction of the desulfoferrodoxin from Desulfoarculus baarsii with superoxide anion. Evidence for a superoxide reductase activity. J Biol Chem 2000, 275(1):115-121.

22. Chen L, Sharma P, Le Gall J, Mariano AM, Teixeira M, Xavier AV: A blue non-heme iron protein from Desulfovibrio gigas. Eur J Biochem 1994, 226(2):613-618.

23. Jenney FE Jr, Verhagen MF, Cui X, Adams MW: Anaerobic microbes: oxygen detoxification without superoxide dismutase. Science 1999, 286(5438):306-309.

24. Pianzzola MJ, Soubes M, Touati D: Overproduction of the rbo gene product from Desulfovibrio species suppresses all deleterious effects of lack of superoxide dismutase in Escherichia coli. J Bacteriol 1996, 178(23):6736-6742.

25. Lombard M, Touati D, Fontecave M, Niviere V: Superoxide reductase as a unique defense system against superoxide stress in the microaerophile Treponema pallidum. J Biol Chem 2000, 275(35):27021-27026

26. Silva G, LeGall J, Xavier AV, Teixeira M, Rodrigues-Pousada C: Molecular characterization of Desulfovibrio gigas neelaredoxin, a protein involved in oxygen detoxification in anaerobes. J Bacterio/ 2001, 183(15):4413-4420.

27. Liochev SI, Fridovich I: A mechanism for complementation of the sodA sodB defect in Escherichia coli by overproduction of the rbo gene product (desulfoferrodoxin) from Desulfoarculus baarsii. J Biol Chem 1997, 272(41):25573-25575.

28. Tulipan DJ, Eaton RG, Eberhart RE: The Darrach procedure defended: technique redefined and long-term follow-up. J Hand Surg Am 1991, 16(3):438-444

29. Clay MD, Jenney FE Jr, Hagedoorn PL, George GN, Adams MW Johnson MK: Spectroscopic studies of Pyrococcus furiosus superoxide reductase: implications for active-site structures and the catalytic mechanism. J Am Chem Soc 2002, 124(5):788-805

30. Yeh AP, Hu Y, Jenney FE Jr, Adams MW, Rees DC: Structures of the superoxide reductase from Pyrococcus furiosus in the oxidized and reduced states. Biochemistry 2000, 39(10):2499-2508.

31. Coelho AV, Matias PM, Fulop V, Thompson A, Gonzalez A, Carrondo MA: Desulfoferrodoxin structure determined by MAD phasing and refinement to $1.9-\AA \AA$ resolution reveals a unique combination of a tetrahedral FeS4 centre with a square pyramidal FeSN4 centre. J Biol Inorg Chem 1997, 2(6):680-689.

32. Archer M, Huber R, Tavares P, Moura I, Moura JJ, Carrondo MA, Sieker LC, LeGall J, Romao MJ: Crystal structure of desulforedoxin from Desulfovibrio gigas determined at $1.8 \mathrm{~A}$ resolution: a novel non-heme iron protein structure. J Mol Biol 1995, 251(5):690-702.

33. Kurtz DM Jr, Coulter ED: The mechanism(s) of superoxide reduction by superoxide reductases in vitro and in vivo. J Biol Inorg Chem 2002, 7(6):653-658.

34. Pereira SA, Tavares P, Folgosa F, Almeida RM, Moura I, Moura JJG: European Journal of Inorganic Chemistry. European Journal of Inorganic Chemistry 2007, 2007(18):2569-2581.

35. Jovanovic T, Ascenso C, Hazlett KR, Sikkink R, Krebs C, Litwiller R, Benson LM, Moura I, Moura JJ, Radolf JD, et al: Neelaredoxin, an ironbinding protein from the syphilis spirochete, Treponema pallidum, is a superoxide reductase. J Biol Chem 2000, 275(37):28439-28448.

36. Thybert D, Avner S, Lucchetti-Miganeh C, Cheron A, Barloy-Hubler F: OxyGene: an innovative platform for investigating oxidative-response genes in whole prokaryotic genomes. BMC Genomics 2008, 9:637.

37. Brioukhanov AL, Netrusov Al: Catalase and superoxide dismutase: distribution, properties, and physiological role in cells of strict anaerobes. Biochemistry (Mosc) 2004, 69(9):949-962.

38. Tally FP, Goldin BR, Jacobus NV, Gorbach SL: Superoxide dismutase in anaerobic bacteria of clinical significance. Infect Immun 1977, 16(1):20-25.

39. Rusnak F, Ascenso C, Moura I, Moura JJ: Superoxide reductase activities of neelaredoxin and desulfoferrodoxin metalloproteins. Methods Enzymol 2002, 349:243-258

40. Niviere $\mathrm{V}$, Fontecave M: Discovery of superoxide reductase: an historical perspective. J Biol Inorg Chem 2004, 9(2):119-123.

41. Pinto AF, Rodrigues $J V$, Teixeira M: Reductive elimination of superoxide: Structure and mechanism of superoxide reductases. Biochim Biophys Acta 2010, 1804(2):285-297. 
42. Skovgaard $M$, Jensen $L$, Brunak $S$, Ussery D, Krogh A: On the total number of genes and their length distribution in complete microbial genomes. Trends Genet 2001, 17(8):425-428

43. Dolla A, Fournier M, Dermoun Z: Oxygen defense in sulfate-reducing bacteria. J Biotechnol 2006, 126(1):87-100.

44. Altschul SF, Gish W, Miller W, Myers EW, Lipman DJ: Basic local alignment search tool. J Mol Biol 1990, 215(3):403-410.

45. Gertz EM, Yu YK, Agarwala R, Schaffer AA, Altschul SF: Composition-based statistics and translated nucleotide searches: improving the TBLASTN module of BLAST. BMC Biol 2006, 4:41.

46. Thompson JD, Higgins DG, Gibson TJ: CLUSTAL W: improving the sensitivity of progressive multiple sequence alignment through sequence weighting, position-specific gap penalties and weight matrix choice. Nucleic Acids Res 1994, 22(22):4673-4680

47. Higgins DG, Thompson JD, Gibson TJ: Using CLUSTAL for multiple sequence alignments. Methods Enzymol 1996, 266:383-402.

48. Edgar RC: MUSCLE: a multiple sequence alignment method with reduced time and space complexity. BMC Bioinformatics 2004, 5:113.

49. Koonin EV, Wolf YI, Karev GP: The structure of the protein universe and genome evolution. Nature 2002, 420(6912):218-223.

50. Ponting CP, Russell RR: The natural history of protein domains. Annu Rev Biophys Biomol Struct 2002, 31:45-71.

51. Abreu IA, Saraiva LM, Carita J, Huber H, Stetter KO, Cabelli D, Teixeira M: Oxygen detoxification in the strict anaerobic archaeon Archaeoglobus fulgidus: superoxide scavenging by neelaredoxin. Mol Microbiol 2000, 38(2):322-334.

52. Mathe C, Niviere V, Houee-Levin C, Mattioli TA: Fe(3+)-eta(2)-peroxo species in superoxide reductase from Treponema pallidum. Comparison with Desulfoarculus baarsii. Biophys Chem 2006, 119(1):38-48.

53. Kratzer C, Welte C, Dorner K, Friedrich T, Deppenmeier U: Methanoferrodoxin represents a new class of superoxide reductase containing an iron-sulfur cluster. FEBS J 2011, 278(3):442-451.

54. Coulter ED, Kurtz DM Jr: A role for rubredoxin in oxidative stress protection in Desulfovibrio vulgaris: catalytic electron transfer to rubrerythrin and two-iron superoxide reductase. Arch Biochem Biophys 2001, 394(1):76-86.

55. Rodrigues JV, Saraiva LM, Abreu IA, Teixeira M, Cabelli DE: Superoxide reduction by Archaeoglobus fulgidus desulfoferrodoxin: comparison with neelaredoxin. J Biol Inorg Chem 2007, 12(2):248-256.

56. Coelho AV, Matias PM, Carrondo MA, Tavares P, Moura JJ, Moura I, Fulop V, Hajdu J, Le Gall J: Preliminary crystallographic analysis of the oxidized form of a two mono-nuclear iron centres protein from Desulfovibrio desulfuricans ATCC 27774. Protein Sci 1996, 5(6):1189-1191.

57. Stothard $P$, Wishart DS: Circular genome visualization and exploration using CGView. Bioinformatics 2005, 21(4):537-539.

58. Petkau A, Stuart-Edwards M, Stothard P, Van Domselaar G: Interactive Microbial Genome Visualization with GView. Bioinformatics 2010

59. Goudenege D, Avner S, Lucchetti-Miganeh C, Barloy-Hubler F: CoBaltDB: Complete bacterial and archaeal orfeomes subcellular localization database and associated resources. BMC Microbiol 2010, 10:88.

60. Pruesse E, Quast C, Knittel K, Fuchs BM, Ludwig W, Peplies J, Glockner FO: SILVA: a comprehensive online resource for quality checked and aligned ribosomal RNA sequence data compatible with ARB. Nucleic Acids Res 2007, 35(21):7188-7196.

61. Barns SM, Delwiche CF, Palmer JD, Dawson SC, Hershberger KL, Pace NR: Phylogenetic perspective on microbial life in hydrothermal ecosystems, past and present. Ciba Found Symp 1996, 202:24-32, discussion 32-29..

62. Huber H, Hohn MJ, Rachel R, Fuchs T, Wimmer VC, Stetter KO: A new phylum of Archaea represented by a nanosized hyperthermophilic symbiont. Nature 2002, 417(6884):63-67.

63. Paper W, Jahn U, Hohn MJ, Kronner M, Nather DJ, Burghardt T, Rachel R, Stetter $\mathrm{KO}$, Huber $\mathrm{H}$ : Ignicoccus hospitalis sp. nov., the host of 'Nanoarchaeum equitans'. Int J Syst Evol Microbiol 2007, 57(Pt 4):803-808.

64. Burggraf S, Huber H, Stetter KO: Reclassification of the crenarchael orders and families in accordance with 165 rRNA sequence data. Int I Syst Bacteriol 1997, 47(3):657-660.

65. Kawarabayasi Y, Hino Y, Horikawa H, Yamazaki S, Haikawa Y, Jin-no K, Takahashi M, Sekine M, Baba S, Ankai A, et al: Complete genome sequence of an aerobic hyper-thermophilic crenarchaeon, Aeropyrum pernix K1. DNA Res 1999, 6(2):83-101, 145-152.

66. Lee HJ, Kwon HW, Koh JU, Lee DK, Moon JY, Kong KH: An efficient method for the expression and reconstitution of thermostable $\mathrm{Mn} / \mathrm{Fe}$ superoxide dismutase from Aeropyrum pernix K1. J Microbiol Biotechnol 2010, 20(4):727-731.

67. Niederberger TD, Gotz DK, McDonald IR, Ronimus RS, Morgan HW: Ignisphaera aggregans gen. nov., sp. nov., a novel hyperthermophilic crenarchaeote isolated from hot springs in Rotorua and Tokaanu, New Zealand. Int J Syst Evol Microbiol 2006, 56(Pt 5):965-971.

68. Rose RW, Bruser T, Kissinger JC, Pohlschroder M: Adaptation of protein secretion to extremely high-salt conditions by extensive use of the twin-arginine translocation pathway. Mol Microbiol 2002, 45(4):943-950

69. Bendtsen JD, Nielsen H, Widdick D, Palmer T, Brunak S: Prediction of twinarginine signal peptides. BMC Bioinformatics 2005, 6:167.

70. Hafenbradl D, Keller M, Dirmeier R, Rachel R, Rossnagel P, Burggraf S, Huber H, Stetter KO: Ferroglobus placidus gen. nov., sp. nov., A novel hyperthermophilic archaeum that oxidizes $\mathrm{Fe} 2+$ at neutral $\mathrm{pH}$ under anoxic conditions. Arch Microbiol 1996, 166(5):308-314.

71. Klenk HP, Clayton RA, Tomb JF, White O, Nelson KE, Ketchum KA, Dodson RJ, Gwinn M, Hickey EK, Peterson JD, et al: The complete genome sequence of the hyperthermophilic, sulphate-reducing archaeon Archaeoglobus fulgidus. Nature 1997, 390(6658):364-370.

72. Burggraf S, Jannasch HW, Nicolaus B, Stetter KO: Archaeoglobus profundus sp. nov., represents a new species within the sulfate-reducing archaebacteria. Syst Appl Microbiol 1990, 13:24-28.

73. Fomenko DE, Gladyshev VN: Identity and functions of CxxC-derived motifs. Biochemistry 2003, 42(38):11214-11225.

74. Ladenstein R, Ren B: Reconsideration of an early dogma, saying "there is no evidence for disulfide bonds in proteins from archaea". Extremophiles 2008, 12(1):29-38.

75. Maeder DL, Anderson I, Brettin TS, Bruce DC, Gilna P, Han CS, Lapidus A, Metcalf WW, Saunders E, Tapia R, et al: The Methanosarcina barkeri genome: comparative analysis with Methanosarcina acetivorans and Methanosarcina mazei reveals extensive rearrangement within methanosarcinal genomes. J Bacteriol 2006, 188(22):7922-7931.

76. Devreese B, Tavares P, Lampreia J, Van Damme N, Le Gall J, Moura JJ, Van Beeumen J, Moura I: Primary structure of desulfoferrodoxin from Desulfovibrio desulfuricans ATCC 27774, a new class of non-heme iron proteins. FEBS Lett 1996, 385(3):138-142.

77. Tavares P, Ravi N, Moura JJ, LeGall J, Huang YH, Crouse BR, Johnson MK, Huynh BH, Moura I: Spectroscopic properties of desulfoferrodoxin from Desulfovibrio desulfuricans (ATCC 27774). J Biol Chem 1994, 269(14):10504-10510

78. Romao CV, Liu MY, Le Gall J, Gomes CM, Braga V, Pacheco I, Xavier AV, Teixeira M: The superoxide dismutase activity of desulfoferrodoxin from Desulfovibrio desulfuricans ATCC 27774. Eur J Biochem 1999, 261(2):438-443.

79. Adam V, Royant A, Niviere V, Molina-Heredia FP, Bourgeois D: Structure of superoxide reductase bound to ferrocyanide and active site expansion upon X-ray-induced photo-reduction. Structure 2004, 12(9):1729-1740.

80. Katona G, Carpentier P, Niviere V, Amara P, Adam V, Ohana J, Tsanov N, Bourgeois D: Raman-assisted crystallography reveals end-on peroxide intermediates in a nonheme iron enzyme. Science 2007, 316(5823):449-453.

81. Niviere V, Asso M, Weill CO, Lombard M, Guigliarelli B, Favaudon V, HoueeLevin C: Superoxide reductase from Desulfoarculus baarsii: identification of protonation steps in the enzymatic mechanism. Biochemistry 2004, 43(3):808-818.

82. Mathe C, Mattioli TA, Horner O, Lombard M, Latour JM, Fontecave M, Niviere V: Identification of iron(III) peroxo species in the active site of the superoxide reductase SOR from Desulfoarculus baarsii. J Am Chem Soc 2002, 124(18):4966-4967.

83. Mathe C, Weill CO, Mattioli TA, Berthomieu C, Houee-Levin C, Tremey E, Niviere $V$ : Assessing the role of the active-site cysteine ligand in the superoxide reductase from Desulfoarculus baarsii. J Biol Chem 2007, 282(30):22207-22216

84. Mathe C, Niviere V, Mattioli TA: Fe3+-hydroxide ligation in the superoxide reductase from Desulfoarculus baarsii is associated with $\mathrm{pH}$ dependent spectral changes. J Am Chem Soc 2005, 127(47):16436-16441.

85. Horner O, Mouesca JM, Oddou JL, Jeandey C, Niviere V, Mattioli TA, Mathe C, Fontecave M, Maldivi P, Bonville P, et al: Mossbauer characterization of an unusual high-spin side-on peroxo-Fe3+ species in the active site of superoxide reductase from Desulfoarculus Baarsii. 
Density functional calculations on related models. Biochemistry 2004, 43(27):8815-8825.

86. Berthomieu C, Dupeyrat F, Fontecave M, Vermeglio A, Niviere V: Redoxdependent structural changes in the superoxide reductase from Desulfoarculus baarsii and Treponema pallidum: a FTIR study. Biochemistry 2002, 41(32):10360-10368.

87. Bonnot F, Houee-Levin C, Favaudon V, Niviere V: Photochemical processes observed during the reaction of superoxide reductase from Desulfoarculus baarsii with superoxide: re-evaluation of the reaction mechanism. Biochim Biophys Acta 2010, 1804(4):762-767.

88. Clay MD, Jenney FE Jr, Noh HJ, Hagedoorn PL, Adams MW, Johnson MK: Resonance Raman characterization of the mononuclear iron active-site vibrations and putative electron transport pathways in Pyrococcus furiosus superoxide reductase. Biochemistry 2002, 41(31):9833-9841.

89. Grunden AM, Jenney FE Jr, Ma K, Ji M, Weinberg MV, Adams MW: In vitro reconstitution of an NADPH-dependent superoxide reduction pathway from Pyrococcus furiosus. Appl Environ Microbiol 2005, 71(3):1522-1530.

90. Clay MD, Cosper CA, Jenney FE Jr, Adams MW, Johnson MK: Nitric oxide binding at the mononuclear active site of reduced Pyrococcus furiosus superoxide reductase. Proc Natl Acad Sci USA 2003, 100(7):3796-3801.

91. Im YJ, Ji M, Lee A, Killens R, Grunden AM, Boss WF: Expression of Pyrococcus furiosus superoxide reductase in Arabidopsis enhances heat tolerance. Plant Physiol 2009, 151(2):893-904.

92. Santos-Silva T, Trincao J, Carvalho AL, Bonifacio C, Auchere F, Raleiras P, Moura I, Moura JJ, Romao MJ: The first crystal structure of class III superoxide reductase from Treponema pallidum. J Biol Inorg Chem 2006, 11(5):548-558.

93. Santos-Silva T, Trincao J, Carvalho AL, Bonifacio C, Auchere F, Moura I, Moura JJ, Romao MJ: Superoxide reductase from the syphilis spirochete Treponema pallidum: crystallization and structure determination using soft X-rays. Acta Crystallogr Sect F Struct Biol Cryst Commun 2005, 61(Pt 11):967-970

94. Niviere V, Lombard M, Fontecave M, Houee-Levin C: Pulse radiolysis studies on superoxide reductase from Treponema pallidum. FEBS Lett 2001, 497(2-3):171-173.

95. Auchere F, Sikkink R, Cordas C, Raleiras P, Tavares P, Moura I, Moura JJ: Overexpression and purification of Treponema pallidum rubredoxin; kinetic evidence for a superoxide-mediated electron transfer with the superoxide reductase neelaredoxin. J Biol Inorg Chem 2004, 9(7):839-849.

96. Hazlett KR, Cox DL, Sikkink RA, Auch'ere F, Rusnak F, Radolf JD: Contribution of neelaredoxin to oxygen tolerance by Treponema pallidum. Methods Enzymol 2002, 353:140-156.

97. Auchere F, Raleiras P, Benson L, Venyaminov SY, Tavares P, Moura JJ, Moura I, Rusnak F: Formation of a stable cyano-bridged dinuclear iron cluster following oxidation of the superoxide reductases from Treponema pallidum and Desulfovibrio vulgaris with $\mathrm{K}(3) \mathrm{Fe}(\mathrm{CN})(6)$. Inorg Chem 2003, 42(4):938-940.

98. Lombard M, Houee-Levin C, Touati D, Fontecave M, Niviere V: Superoxide reductase from Desulfoarculus baarsii: reaction mechanism and role of glutamate 47 and lysine 48 in catalysis. Biochemistry 2001, 40(16):5032-5040.

99. Niviere V, Lombard M: Superoxide reductase from Desulfoarculus baarsii. Methods Enzymol 2002, 349:123-129.

100. Bandeiras TM, Romao CV, Rodrigues JV, Teixeira M, Matias PM: Purification, crystallization and X-ray crystallographic analysis of Archaeoglobus fulgidus neelaredoxin. Acta Crystallogr Sect F Struct Biol Cryst Commun 2010, 66(Pt 3):316-319

101. Rodriques JV, Abreu IA, Cabelli D, Teixeira M: Superoxide reduction mechanism of Archaeoglobus fulgidus one-iron superoxide reductase. Biochemistry 2006, 45(30):9266-9278.

102. Todorovic S, Rodrigues JV, Pinto AF, Thomsen C, Hildebrandt P, Teixeira M, Murgida DH: Resonance Raman study of the superoxide reductase from Archaeoglobus fulgidus, E12 mutants and a 'natural variant'. Phys Chem Chem Phys 2009, 11(11):1809-1815.

103. Abreu IA, Saraiva LM, Soares CM, Teixeira M, Cabelli DE: The mechanism of superoxide scavenging by Archaeoglobus fulgidus neelaredoxin. $J$ Biol Chem 2001, 276(42):38995-39001.

104. Kitamura M, Koshino Y, Kamikawa Y, Kohno K, Kojima S, Miura K, Sagara T, Akutsu H, Kumagai I, Nakaya T: Cloning and expression of the rubredoxin gene from Desulfovibrio vulgaris (Miyazaki F)-comparison of the primary structure of desulfoferrodoxin. Biochim Biophys Acta 1997, 1351(1-2):239-247.

105. Huang WW, Emerson JP, Kurtz DM Jr: Reaction of Desulfovibrio vulgaris two-iron superoxide reductase with superoxide: insights from stoppedflow spectrophotometry. Biochemistry 2007, 46(40):11342-11351.

106. Wildschut JD, Lang RM, Voordouw JK, Voordouw G: Rubredoxin:oxygen oxidoreductase enhances survival of Desulfovibrio vulgaris hildenborough under microaerophilic conditions. J Bacteriol 2006, 188(17):6253-6260.

107. Clay MD, Emerson JP, Coulter ED, Kurtz DM Jr, Johnson MK: Spectroscopic characterization of the $[\mathrm{Fe}(\mathrm{His})(4)(\mathrm{Cys})]$ site in 2Fe-superoxide reductase from Desulfovibrio vulgaris. J Biol Inorg Chem 2003, 8(6):671-682.

108. Emerson JP, Coulter ED, Cabelli DE, Phillips RS, Kurtz DM Jr: Kinetics and mechanism of superoxide reduction by two-iron superoxide reductase from Desulfovibrio vulgaris. Biochemistry 2002, 41(13):4348-4357.

109. Silva G, Oliveira S, Gomes CM, Pacheco I, Liu MY, Xavier AV, Teixeira M, Legall J, Rodrigues-pousada C: Desulfovibrio gigas neelaredoxin. A novel superoxide dismutase integrated in a putative oxygen sensory operon of an anaerobe. Eur J Biochem 1999, 259(1-2):235-243.

110. Riebe O, Fischer RJ, Bahl H: Desulfoferrodoxin of Clostridium acetobutylicum functions as a superoxide reductase. FEBS Lett 2007, 581(29):5605-5610

111. Kawasaki S, Sakai Y, Takahashi T, Suzuki I, Niimura Y: O2 and reactive oxygen species detoxification complex, composed of O2-responsive NADH:rubredoxin oxidoreductase-flavoprotein A2-desulfoferrodoxin operon enzymes, rubperoxin, and rubredoxin, in Clostridium acetobutylicum. Appl Environ Microbiol 2009, 75(4):1021-1029.

112. Rodrigues JV, Victor BL, Huber H, Saraiva LM, Soares CM, Cabelli DE, Teixeira M: Superoxide reduction by Nanoarchaeum equitans neelaredoxin, an enzyme lacking the highly conserved glutamate iron ligand. J Biol Inorg Chem 2008, 13(2):219-228.

113. Clamp M, Cuff J, Searle SM, Barton GJ: The Jalview Java alignment editor. Bioinformatics 2004, 20(3):426-427.

114. Waterhouse AM, Procter JB, Martin DM, Clamp M, Barton GJ: Jalview Version 2-a multiple sequence alignment editor and analysis workbench. Bioinformatics 2009, 25(9):1189-1191.

\section{doi:10.1186/1471-2180-11-105}

Cite this article as: Lucchetti-Miganeh et al: SORGOdb: Superoxide Reductase Gene Ontology curated DataBase. BMC Microbiology 2011 11:105.

\section{Submit your next manuscript to BioMed Central and take full advantage of:}

- Convenient online submission

- Thorough peer review

- No space constraints or color figure charges

- Immediate publication on acceptance

- Inclusion in PubMed, CAS, Scopus and Google Scholar

- Research which is freely available for redistribution 